\title{
Investigations on juvenile fish excluder cum shrimp sorting device (JFE-SSD)
}

\author{
Menothuparambil Ravunny Boopendranath ${ }^{*}$, Puthra Pravin ${ }^{1}$, Therodath Rajan Gibinkumar ${ }^{2}$, Sarasan Sabu ${ }^{3}$ \\ and Vettiyattil Ramakrishnan Madhu'
}

\begin{abstract}
Penaeid shrimp is a major resource in India contributing about $7.4 \%$ of the total marine fish landings. They are mostly landed by small mechanized trawlers. Shrimp trawling generates large quantities of bycatch mostly consisting of juvenile fishes, due to use of small mesh size in codends of trawl nets. Juvenile Fish Excluder cum Shrimp Sorting Device (JFE-SSD) is a bycatch reduction device with an in situ sorting mechanism, which replaces the conventional codend in a trawl. The device was designed to catch shrimps and commercially important fish species using a specially designed oval sorting grid with appropriate bar spacing and dual codends. Shrimp sorting efficiency and bycatch exclusion characteristics of JFE-SSD attached to a $29.6 \mathrm{~m}$ shrimp trawl, was tested by experimental fishing along the coastal waters off Cochin, India. Out of a total of $317.07 \mathrm{~kg}$ of catch encountered in the JFE-SSD installed trawl, 58.22\% was retained in lower codend, $17.53 \%$ in upper codend and $24.25 \%$, mostly consisting of juveniles and sub-adults of finfishes and shellfishes, was excluded from upper codend. The mean CPUE registered for upper and lower codend were 7.23 \pm 1.04 SE and 5.84 $\pm 0.96 \mathrm{SE} \mathrm{kg} \mathrm{h}{ }^{-1}$ respectively. The CPUE of shrimps retained in upper and lower codends were significantly different (Kruskal-Wallis test $(1,62), P<0.001$ ), but the mean CPUE for fishes did not vary significantly. The average escapement of shrimps and juvenile fishes from upper codend were $0.06 \pm 0.02 \mathrm{SE} \mathrm{kg} \mathrm{h}^{-1}$ and $2.40 \pm 0.44 \mathrm{SE} \mathrm{kg} \mathrm{h}{ }^{-1}$ respectively. Significant differences in the length composition between upper and lower codends were noticed for Megalaspis cordyla, Stolephorus waitei, Metapenaeus dobsoni and Parapenaeopsis stylifera. The experiments demonstrated in situ sorting ability of the device and its potential to reduce the bycatch of juveniles and sub-adults in shrimp trawls.
\end{abstract}

Keywords: Juvenile fish excluder cum shrimp sorting device, JFE-SSD, Bycatch reduction, Shrimp trawl

\section{Background}

Shrimp trawling is a major economic activity in India and elsewhere in tropical fisheries. Average annual landings of penaeid shrimps in India, during 2010-2011, has been 0.26 million tonnes which formed $7.4 \%$ of the total marine fish landings (CMFRI 2013). They are mostly landed by small mechanized trawlers. It is well known that the shrimp trawling is a non-selective fishing method resulting in significant qantities of bycatch and discards (Kelleher 2005; Boopendranath et al. 2008, 2010; Pramod 2010). Different types of bycatch reduction technologies have been developed in the fishing industry around the world with a view to reduce the bycatch and discards from

\footnotetext{
* Correspondence: boopendranath@hotmail.com

${ }^{1}$ Central Institute of Fisheries Technology, CIFT Junction, P.O. Matsyapuri, Cochin 682 029, India

Full list of author information is available at the end of the article
}

trawling (Broadhurst 2000; Kennelly and Broadhurst 2002; CEFAS 2003; Eayrs 2007; Kennelly 2007; Boopendranath et al. 2008, 2010; Boopendranath 2009, 2012; Pravin et al. 2011; Broadhurst et al. 2012; Suuronen et al. 2012). Fishermen in India and elsewhere in tropical fisheries do not accept complete exclusion of fish and cephalopods during shrimp trawling, due to economic considerations (Boopendranath et al. 2008). Finfish species, crabs and cephalopods contribute significantly to the fishermen's income. In small-scale mechanized trawl fisheries of India, shrimp fishermen spend a lot of time for sorting the catch onboard after they are landed, which cuts into their productive fishing time (Boopendranath et al. 2008). The struggle of large fishes accumulated in codend tend to damage shrimps leading to reduction in quality of the shrimp catch (Salini et al. 2000).

\section{Springer}


Table 1 Species-wise catch distribution in upper codend, lower codend and upper codend cover and exclusion rates from upper codend in JFE-SSD installed operations

\begin{tabular}{|c|c|c|c|c|c|}
\hline & $\begin{array}{l}\text { Encountered } \\
\text { catch, kg }\end{array}$ & $\begin{array}{c}\text { Lower } \\
\text { codend, } \%\end{array}$ & $\begin{array}{c}\text { Upper } \\
\text { codend, \% }\end{array}$ & $\begin{array}{l}\text { Upper codend } \\
\text { cover, } \%\end{array}$ & $\begin{array}{l}\text { Exclusion rate from } \\
\text { upper codend, \% }\end{array}$ \\
\hline \multicolumn{6}{|l|}{ Finfishes } \\
\hline Alepes kleinii & 3.35 & 47.01 & 4.93 & 48.06 & 48.06 \\
\hline Ambassis ambassis & 4.33 & 42.38 & 11.89 & 45.73 & 45.73 \\
\hline Anadontostoma chacunda & 1.15 & 28.70 & 56.52 & 14.78 & 14.78 \\
\hline Arius jella & 2.67 & 28.09 & 51.87 & 20.04 & 20.04 \\
\hline Cynoglossus arel & 0.86 & 23.98 & 14.62 & 61.40 & 61.40 \\
\hline Cynoglossus macrostomus & 7.06 & 65.58 & 12.39 & 22.03 & 22.03 \\
\hline Epinephelus diacanthus & 4.84 & 31.40 & 22.21 & 46.38 & 42.16 \\
\hline Escualosa thoracata & 1.46 & 59.79 & 2.41 & 37.80 & 46.38 \\
\hline Gerres erythrourus & 1.13 & 46.22 & 21.33 & 32.44 & 37.80 \\
\hline Johnius borneensis & 7.63 & 46.85 & 24.64 & 28.51 & 19.53 \\
\hline Johnius carouna & 0.78 & 14.10 & 57.69 & 28.21 & 32.44 \\
\hline Johnius carutta & 2.23 & 18.88 & 54.38 & 26.74 & 28.51 \\
\hline Lactarius lactarius & 1.10 & 30.14 & 16.89 & 52.97 & 28.21 \\
\hline Leiognathus dussumieri & 1.00 & 42.21 & 10.05 & 47.74 & 26.74 \\
\hline Leiognathus equulus & 1.03 & 65.37 & 4.88 & 29.76 & 52.97 \\
\hline Eubleekeria splendens & 8.66 & 57.65 & 22.82 & 19.53 & 47.74 \\
\hline Liza parsia & 1.02 & 32.84 & 14.71 & 52.45 & 52.45 \\
\hline Megalaspis cordyla & 3.65 & 11.10 & 34.11 & 54.79 & 54.79 \\
\hline Mugil cephalus & 2.71 & 82.29 & 2.21 & 15.50 & 34.42 \\
\hline Opisthopterus tardoore & 1.58 & 40.63 & 57.14 & 2.22 & 19.70 \\
\hline Otolithes ruber & 1.49 & 20.81 & 30.87 & 48.32 & 2.22 \\
\hline Pampus argenteus & 3.18 & 0.00 & 100.00 & 0.00 & 3.28 \\
\hline Pellona ditchella & 1.53 & 45.75 & 8.50 & 45.75 & 0.00 \\
\hline Rastrelliger kanagurta & 8.93 & 30.52 & 32.53 & 36.95 & 3.14 \\
\hline Sardinella albella & 1.79 & 46.78 & 17.93 & 35.29 & 33.54 \\
\hline Sardinella longiceps & 43.64 & 37.03 & 15.96 & 47.00 & 36.95 \\
\hline Scoliodon laticaudus & 0.35 & 0.00 & 100.00 & 0.00 & 35.29 \\
\hline Secutor insidiator & 5.27 & 32.86 & 30.77 & 36.37 & 47.00 \\
\hline Stolephorus waitei & 1.10 & 73.52 & 13.70 & 12.79 & 36.37 \\
\hline Thryssa mystax & 3.37 & 35.91 & 29.38 & 34.72 & 12.79 \\
\hline Trypauchen vagina & 0.85 & 5.88 & 76.47 & 17.65 & 34.72 \\
\hline \multicolumn{6}{|l|}{ Shrimps } \\
\hline Metapenaeus dobsoni & 49.67 & 95.62 & 1.57 & 2.80 & 2.80 \\
\hline Parapenaeopsis stylifera & 6.47 & 97.74 & 0.43 & 1.82 & 48.32 \\
\hline Penaeus monodon & 0.80 & 2.52 & 94.34 & 3.14 & 1.82 \\
\hline \multicolumn{6}{|l|}{ Crabs } \\
\hline Charybdis ferriatus & 0.88 & 17.71 & 61.14 & 21.14 & 21.14 \\
\hline Doclea ovis & 9.57 & 30.93 & 26.91 & 42.16 & 29.76 \\
\hline Portunus sanguinolentus & 8.95 & 25.21 & 41.25 & 33.54 & 45.75 \\
\hline
\end{tabular}


Table 1 Species-wise catch distribution in upper codend, lower codend and upper codend cover and exclusion rates from upper codend in JFE-SSD installed operations (Continued)

\begin{tabular}{|c|c|c|c|c|c|}
\hline \multicolumn{6}{|l|}{ Stomatopods } \\
\hline \multicolumn{6}{|l|}{$\begin{array}{l}\text { Stomatopods } \\
\text { Oratosquilla nepa }\end{array}$} \\
\hline Molluscan shells & 79.38 & 63.21 & 17.09 & 19.70 & 0.00 \\
\hline Miscellaneous unidentified species & 11.71 & 43.21 & 22.37 & 34.42 & 17.65 \\
\hline All species & 317.07 & 58.22 & 17.53 & 24.25 & 24.25 \\
\hline
\end{tabular}

A number of bycatch reduction devices have been developed in different parts of the world, for shrimp fisheries (Kendall 1990; Isaksen et al. 1992; Rogers et al. 1997; Brewer et al. 1998; Robins and McGilvray 1999; Broadhurst 2000; Kennelly and Broadhurst 2002; CEFAS 2003; Courtney et al. 2006; Criales-Hernandez et al. 2006; Eayrs 2007; Eayrs et al. 2007; Hannah and Jones 2007; Heales et al. 2008; Broadhurst et al. 2012). In the present innovation named Juvenile Fish Excluder cum Shrimp Sorting Device (JFE-SSD), exclusion of juveniles and the separation of the catch into shrimp and fish are facilitated, during shrimp trawling. The design concept of JFE-SSD has won the Runner-up prize in International Smart Gear Competition-2005 of World Wildlife Fund (WWF 2005). The aims of the present study were to (i) assess the general performance of the JFE-SSD by experimental fishing in the conventional shrimp trawling grounds, off Cochin, (ii) assess sorting characteristics due to the installation of the JFE-SSD and (iii) quantify the escapement of shrimps and juveniles of fishes, through upper codend of JFE-SSD.

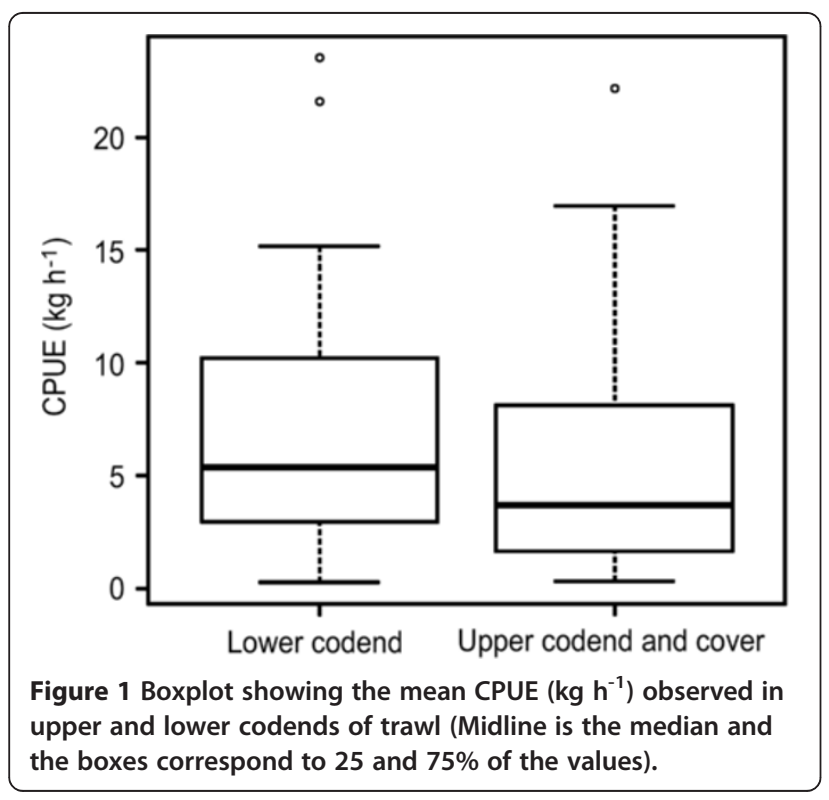

\section{Results and discussion}

CPUE and catch composition in upper and lower codends of JFE-SSD

Out of a total of $317.07 \mathrm{~kg}$ of catch landed during 31 hauls, $58.22 \%$ was retained in lower codend, $17.53 \%$ in upper codend and $24.25 \%$ mostly consisting of juveniles and subadults of finfishes and shellfishes was excluded from upper codend and retained in upper codend cover (Table 1). The mean catch per unit effort (CPUE) recorded for upper codend plus cover and lower codend were 5.84 $\pm 0.96 \mathrm{SE}$ and $7.23 \pm 1.04 \mathrm{SE} \mathrm{kg} \mathrm{h}^{-1}$, respectively (Figure 1) and the difference in the means was not significant $(\mathrm{F}(1,60)=1.22$, $P=0.27)$.

The retention of shrimps in upper and lower codends was $2.82 \%$ and $97.18 \%$, respectively, which indicates good segregation of shrimps in the JFE-SSD (Table 2). The mean CPUE of shrimps in upper and lower codends was $0.11 \pm$ $0.05 \mathrm{SE}$ and $2.03 \pm 0.43 \mathrm{SE} \mathrm{kg} \mathrm{h}^{-1}$ respectively. The mean CPUE of shrimps retained in upper and lower codends of the trawl were significantly different (Kruskal-Wallis test $(1,62), P<0.001)$.

The mean CPUE of finfishes in upper codend was $3.91 \pm 0.59 \mathrm{SE} \mathrm{kg} \mathrm{h}{ }^{-1}$ contributing $66.95 \%$ of the total CPUE of finfishes. The mean CPUE for finfishes in lower codend was $2.26 \pm 0.27 \mathrm{SE} \mathrm{kg} \mathrm{h}^{-1}$, which formed $31.26 \%$ of the total CPUE. No significant difference was noticed in the mean CPUE of finfishes between upper and lower codends (Kruskal-Wallis test (1,62), $P=0.12$ ) (Figure 2). The mean CPUE for total catch observed in the fishing ground with traditional codends has been reported to be $10.7 \mathrm{~kg} \mathrm{~h}^{-1}$ (Boopendranath et al. 2008) and, hence, it can be considered that there is no conspicuous difference in the catch rates due to installation of JFE-SSD.

Table 2 In-situ sorting effect on species groups due to installation of JFE-SSD

\begin{tabular}{lccc}
\hline Species groups & $\begin{array}{c}\text { Catch (upper } \\
\text { and lower } \\
\text { codends), kg }\end{array}$ & $\begin{array}{c}\text { Catch in } \\
\text { lower } \\
\text { codend, \% }\end{array}$ & $\begin{array}{c}\text { Catch in } \\
\text { upper } \\
\text { codend, \% }\end{array}$ \\
\hline All species & 240.19 & 76.86 & 23.14 \\
Shrimp species & 55.40 & 97.18 & 2.82 \\
Species other than shrimps & 184.79 & 70.77 & 29.23 \\
\hline
\end{tabular}




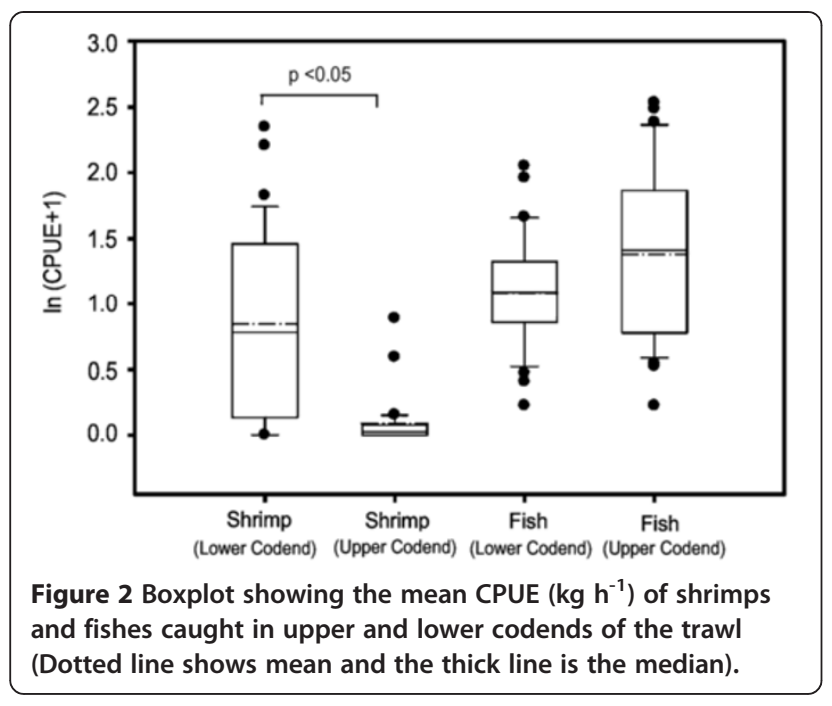

Bycatch exclusion characteristics of JFE-SSD

Species other than shrimps excluded through upper codend of JFE-SSD was $28.96 \%$ by weight. Among the species encountered, four species, viz., Cynoglossus arel, Megalaspis cordyla, Lactarius lactarius and Liza parsia showed exclusion rates in excess of $50 \%$. Nineteen species, viz., Otolithes ruber, Alepes kleinii, Leiognathus dussumieri, Sardinella longiceps, Epinephelus diacanthus, Pellona ditchella, Ambassis ambassis, Doclea ovis, Escualosa thoracata, Rastrelliger kanagurta, Secutor insidiator, Sardinella albella, Thryssa mystax, Portunus sanguinolentus, Gerres erythrourus, Leiognathus equulus, Johnius borneensis, Johnius carouna and Johnius carutta, showed exclusion rates between 25 and $50 \%$ by weight. Species such as

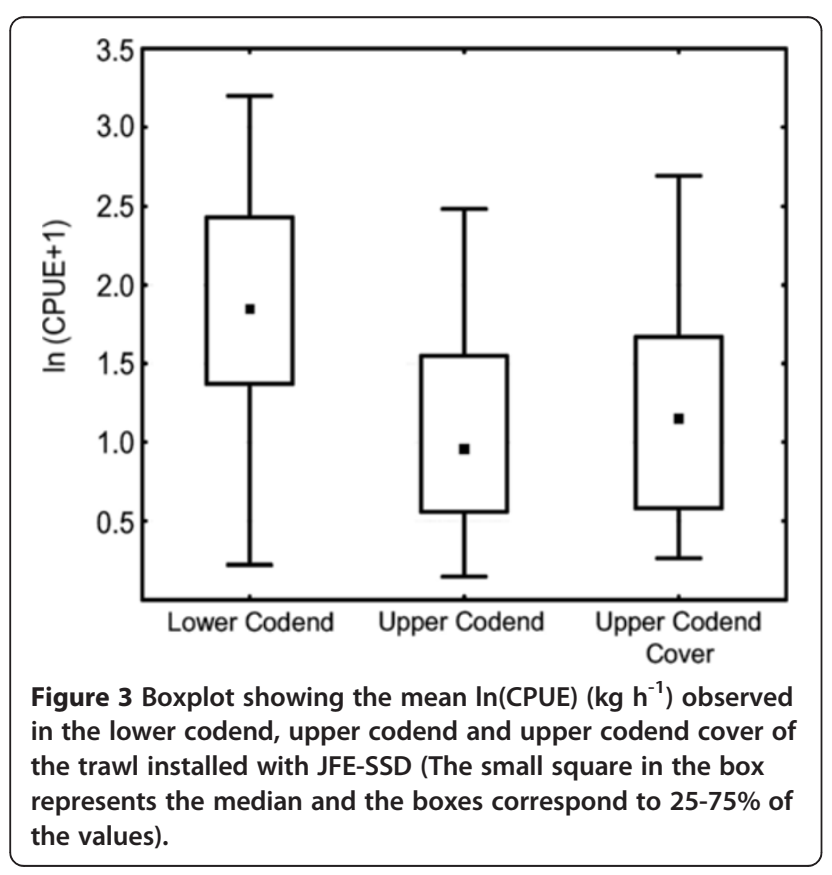

Table 3 Sorting effect on trawl caught species in JFE-SSD

\begin{tabular}{|c|c|c|c|}
\hline Species & $\begin{array}{l}\text { Catch (upper } \\
\text { and lower } \\
\text { codends), kg }\end{array}$ & $\begin{array}{l}\text { Catch in } \\
\text { lower } \\
\text { codend,\% }\end{array}$ & $\begin{array}{l}\text { Catch in } \\
\text { upper } \\
\text { codend, \% }\end{array}$ \\
\hline Oratosquilla nepa & 19.32 & 99.74 & 0.26 \\
\hline Parapenaeopsis stylifera & 6.36 & 99.56 & 0.44 \\
\hline Metapenaeus dobsoni & 48.28 & 98.38 & 1.62 \\
\hline Mugil cephalus & 2.29 & 97.38 & 2.62 \\
\hline Escualosa thoracata & 0.91 & 96.13 & 3.87 \\
\hline Leiognathus equulus & 0.72 & 93.06 & 6.94 \\
\hline Alepes kleinii & 1.74 & 90.52 & 9.48 \\
\hline Pellona ditchella & 0.83 & 84.34 & 15.66 \\
\hline Stolephorus waitei & 0.96 & 84.29 & 15.71 \\
\hline Cynoglossus macrostomus & 5.51 & 84.11 & 15.89 \\
\hline Leiognathus dussumieri & 0.52 & 80.77 & 19.23 \\
\hline Molluscan shells & 63.75 & 78.71 & 21.29 \\
\hline Ambassis ambassis & 2.35 & 78.09 & 21.91 \\
\hline Sardinella albella & 1.16 & 72.29 & 27.71 \\
\hline Eubleekeria splendens & 6.97 & 71.64 & 28.36 \\
\hline Sardinella longiceps & 23.13 & 69.88 & 30.12 \\
\hline Liza parsia & 0.49 & 69.07 & 30.93 \\
\hline Gerres erythrourus & 0.76 & 68.42 & 31.58 \\
\hline Johnius borneensis & 5.46 & 65.54 & 34.46 \\
\hline Lactarius lactarius & 0.52 & 64.08 & 35.92 \\
\hline Cynoglossus arel & 0.33 & 62.12 & 37.88 \\
\hline Epinephelus diacanthus & 2.60 & 58.57 & 41.43 \\
\hline Thryssa mystax & 2.20 & 55.00 & 45.00 \\
\hline Doclea ovis & 5.54 & 53.48 & 46.52 \\
\hline Secutor insidiator & 3.35 & 51.64 & 48.36 \\
\hline Rastrelliger kanagurta & 5.63 & 48.40 & 51.60 \\
\hline Opisthopterus tardoore & 1.54 & 41.56 & 58.44 \\
\hline Otolithes ruber & 0.77 & 40.26 & 59.74 \\
\hline Portunus sanguinolentus & 5.95 & 37.93 & 62.07 \\
\hline Arius jella & 2.14 & 35.13 & 64.87 \\
\hline Anadontostoma chacunda & 0.98 & 33.67 & 66.33 \\
\hline Johnius carutta & 1.63 & 25.77 & 74.23 \\
\hline Megalaspis cordyla & 1.65 & 24.55 & 75.45 \\
\hline Charybdis ferriatus & 0.69 & 22.46 & 77.54 \\
\hline Johnius carouna & 0.56 & 19.64 & 80.36 \\
\hline Trypauchen vagina & 0.70 & 7.14 & 92.86 \\
\hline Penaeus monodon & 0.77 & 2.60 & 97.40 \\
\hline Pampus argenteus & 3.18 & 0.00 & 100.00 \\
\hline Scoliodon laticaudus & 0.35 & 0.00 & 100.00 \\
\hline Miscellaneous species & 7.60 & 65.89 & 34.11 \\
\hline All species & 240.19 & 76.86 & 23.14 \\
\hline
\end{tabular}




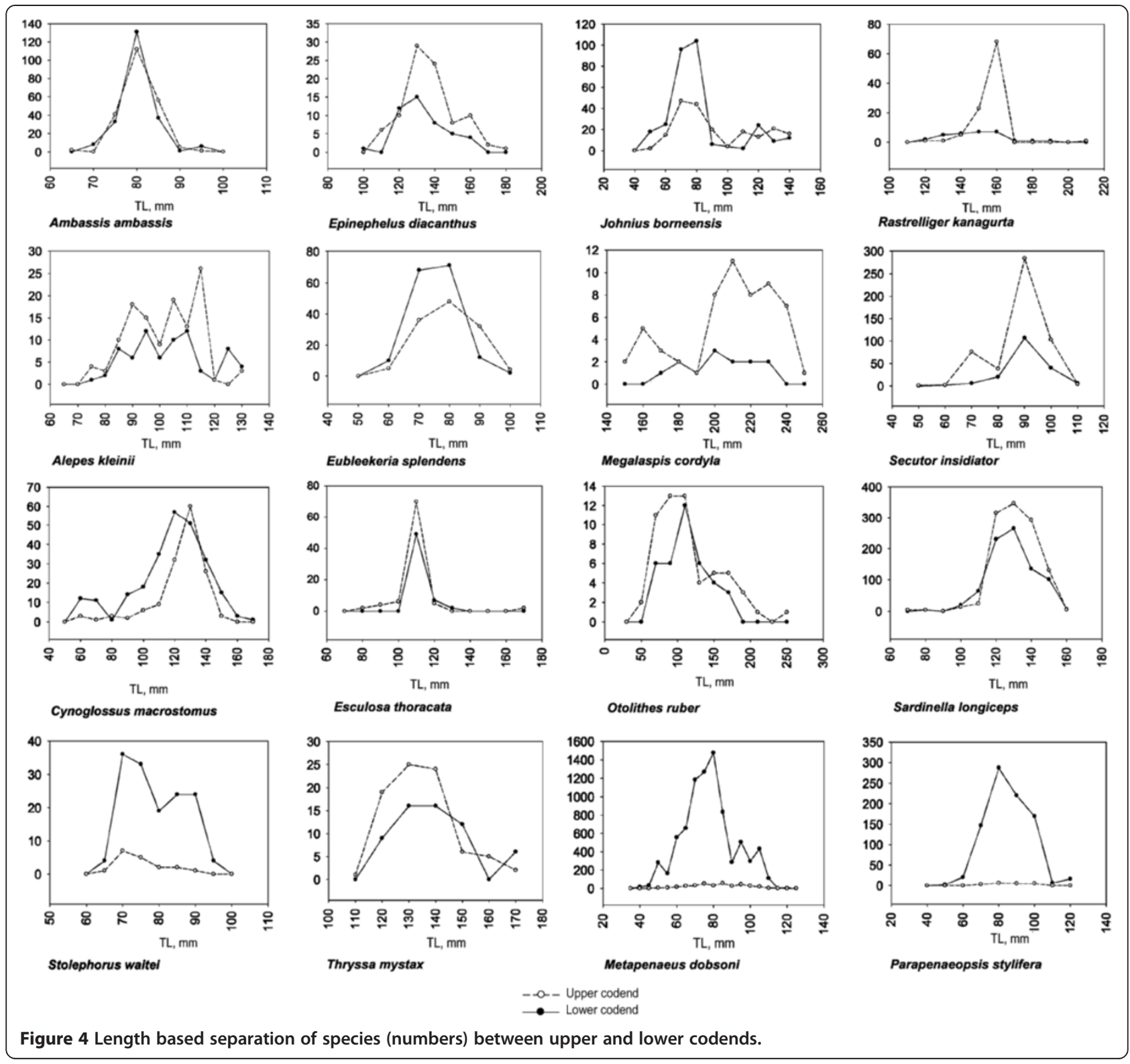

Cynoglossus macrostomus, Charybdis ferriatus, Arius jella, Eubleekeria splendens, Trypauchen vagina, Mugil cephalus, Anadontostoma chacunda, Stolephorus waitei, Oratosquilla nepa, Penaeus monodon, Metapenaeus dobsoni, Opisthopterus tardoore, Parapenaeopsis stylifera and molluscan shells, showed exclusion rates up to $25 \%$ by weight (Table 1 ). Two finfish species, viz., Pampus argenteus and Scoliodon laticaudus were not excluded through JFE-SSD.

The mean escapement from upper codend, expressed as CPUE was significantly higher than zero in case of both fish and shrimp $(\mathrm{t}=2.88, P=0.11, \mathrm{df}=1)$. The average escapement of shrimps from the from upper codend was $0.06 \pm 0.02 \mathrm{SE} \mathrm{kg} \mathrm{h}^{-1}$ and the escapement of juvenile fish from upper codend was $2.40 \pm 0.44 \mathrm{SE} \mathrm{kg} \mathrm{h}^{-1}$ (Figure 3).

\section{Sorting characteristics of JFE-SSD}

Out of a total catch of $240.19 \mathrm{~kg}$ in upper and lower codends, about $77 \%$ was retained in lower codend and the rest in upper codend. Of the retained catch other than shrimps (184.79 kg), 71\% was retained in lower codend and $29 \%$ in upper codend. Out of a total catch of $55.40 \mathrm{~kg}$ of shrimps, about $97 \%$ was retained in lower codend (Table 2). Pampus argenteus and Scoliodon laticaudus was retained $100 \%$ in upper codend. Finfishes such as Trypauchen vagina, Johnius carouna, Megalaspis cordyla, Johnius carutta, Anadontostoma chacunda, Arius jella, Portunus sanguinolentus, Otolithes ruber, Opisthopterus tardoore and Rastrelliger kanagurta and crab species Charybdis ferriatus were retained in upper codend at 
Table 4 Selectivity parameters in respect of selected trawl caught species in JFE-SSD installed operations, during November-December 2005

\begin{tabular}{|c|c|c|c|c|c|}
\hline Species & $\mathrm{L}_{25}(\mathrm{TL}, \mathrm{mm})$ & $\mathrm{L}_{50}(\mathrm{TL}, \mathrm{mm})$ & $\mathrm{L}_{75}(\mathrm{TL}, \mathrm{mm})$ & Selection range $(\mathrm{TL}, \mathrm{mm})$ & $\mathrm{L}_{\mathrm{m}}(\mathrm{TL}, \mathrm{mm})$ \\
\hline Ambassis ambassis & 59.44 & 83.86 & 108.27 & 48.83 & $55-75^{\mathrm{a}}$ \\
\hline Cynoglossus macrostomus & 73.92 & 211.25 & 348.58 & 274.65 & NA \\
\hline Epinephelus diacanthus & 50.97 & 105.9 & 160.83 & 109.86 & $210-377^{a}$ \\
\hline Johnius borneensis & 46.42 & 91.27 & 136.11 & 89.68 & $140-160^{a, b}$ \\
\hline Lepturacanthus savala & 50.05 & 75.02 & 99.99 & 49.94 & $418-750^{a}$ \\
\hline Megalaspis cordyla & 95.67 & 150.6 & 205.53 & 109.86 & $250^{\mathrm{b}}$ \\
\hline Sardinella albella & 109.35 & 140.74 & 172.13 & 62.78 & $90^{b}$ \\
\hline Sardinella longiceps & 17.04 & 126.90 & 236.76 & 219.72 & $150-162^{b}$ \\
\hline Secutor insidiator & 64.63 & 125.67 & 186.70 & 122.07 & $67^{\mathrm{a}}$ \\
\hline Stolephorus waitei & 27.18 & 43.34 & 59.49 & 32.31 & $81-84^{a}$ \\
\hline Thryssa mystax & 98.55 & 156.37 & 214.19 & 115.64 & $130^{\mathrm{a}}$ \\
\hline
\end{tabular}

Source: ${ }^{\mathrm{a}}$ Modayil and Jayaprakash (2003); ${ }^{\mathrm{b}}$ Froese and Pauly (2011).

rates exceeding 50\%. Penaeus monodon also has shown preference to upper codend, though overall catch volume for this species was very low during the period of operations. Shrimp species such as Parapenaeopsis stylifera and Metapenaeus dobsoni; squilla Oratosquilla nepa; finfishes such as Mugil cephalus, Escualosa thoracata, Leiognathus equulus, Alepes kleinii, Pellona ditchella, Stolephorus waitei, Cynoglossus macrostomus, Leiognathus dussumieri, Ambassis ambassis, Sardinella albella, Eubleekeria splendens, Sardinella longiceps, Liza parsia, Gerres erythrourus, Johnius borneensis, Lactarius lactarius, Cynoglossus arel, Epinephelus diacanthus, Thryssa mystax and Secutor insidiator; crab Doclea ovis; and molluscan shells preferentially accumulated in lower codend (Table 3). The sorting effect was very pronounced in shrimp species. However, the sorting of finfish species was not very effective with the grid, probably due to prevalence of juveniles of finfishes. The device may need further optimization in terms of grid bar interspaces and opening to upper codend, to reduce the finfish catches in lower codend.

\section{Length based separation of species between upper and lower codends}

Anderson-Darling K-sample test was used to test the hypothesis of length-based separation of species in upper and lower codends. Significant difference in the length composition between upper and lower codends was noticed for Megalaspis cordyla (larger length groups were represented in upper codend) $(\mathrm{AD}=5.89, P=0.001$, criteria $=0.7, \mathrm{df}=20$ ) and Stolephorus waitei (larger length groups were represented in lower codend) $(\mathrm{AD}=2.15$, $P=0.04$, criteria $=0.69, \mathrm{df}=16$ ). In the case of shrimps, significantly higher catches and larger length groups were noticed in lower codend for Metapenaeus dobsoni $(\mathrm{AD}=$ 7.12, $P=0.001$, criteria $=0.73, \mathrm{df}=36$ ) and Parapenaeopsis stylifera $(\mathrm{AD}=5.23, \quad P=0.003, \quad$ criteria $=0.69, \mathrm{df}=16)$. Length based separation of other species, were not significant statistically. The length based retention and exclusion of selected species caught during the experiments are given in Figure 4.

\section{Selectivity characteristics of JFE-SSD}

Different length classes of juveniles (71-110 mm TL) of Alepes kleinii were excluded through JFE-SSD at rates between 52 and $80 \%$, during the field trials. Length classes of 71-100 mm TL was completely excluded in the case of Escualosa thoracata, while length classes from 101 to $120 \mathrm{~mm}$ TL were excluded at levels of $42-58 \%$ and length classes $>120 \mathrm{~mm}$ TL were fully retained. Juveniles of Otolithes ruber in the length range of $51-170 \mathrm{~mm} \mathrm{TL}$ showed exclusion rates of 40-68\%. Rastrelliger kanagurta above $161 \mathrm{~mm}$ TL were retained while length classes of juveniles below $160 \mathrm{~mm}$ TL were excluded at levels of 77-90\%. Juveniles of Epinephelus diacanthus below $110 \mathrm{~mm}$ TL were excluded, while length classes between 111 and $160 \mathrm{~mm}$ TL were excluded at levels from 46 to $75 \%$. Length classes of Cynoglossus macrostomus above $151 \mathrm{~mm} \mathrm{TL}$ were fully retained while those in 81$150 \mathrm{~mm}$ TL length class were excluded at levels from 13 to $54 \%$ and those in $71-80 \mathrm{~mm}$ length class was excluded at a level of $75 \%$. Adult Sardinella albella in the length class of $156-160 \mathrm{~mm}$ TL were retained while length classes in the 126-155 mm range were excluded at levels ranging from 39 to $70 \%$. Length classes of Secutor insidiator from 51 to $100 \mathrm{~mm}$ TL were excluded at rates ranging from 40 to $93 \%$, while length class below this range (41-50 mm TL) was fully excluded. Length classes of Stolephorus waitei in the range of 61-90 mm TL were excluded at rates ranging from 4 to $16 \%$ while adult length class above this (91-96 mm TL) was fully retained. In the 

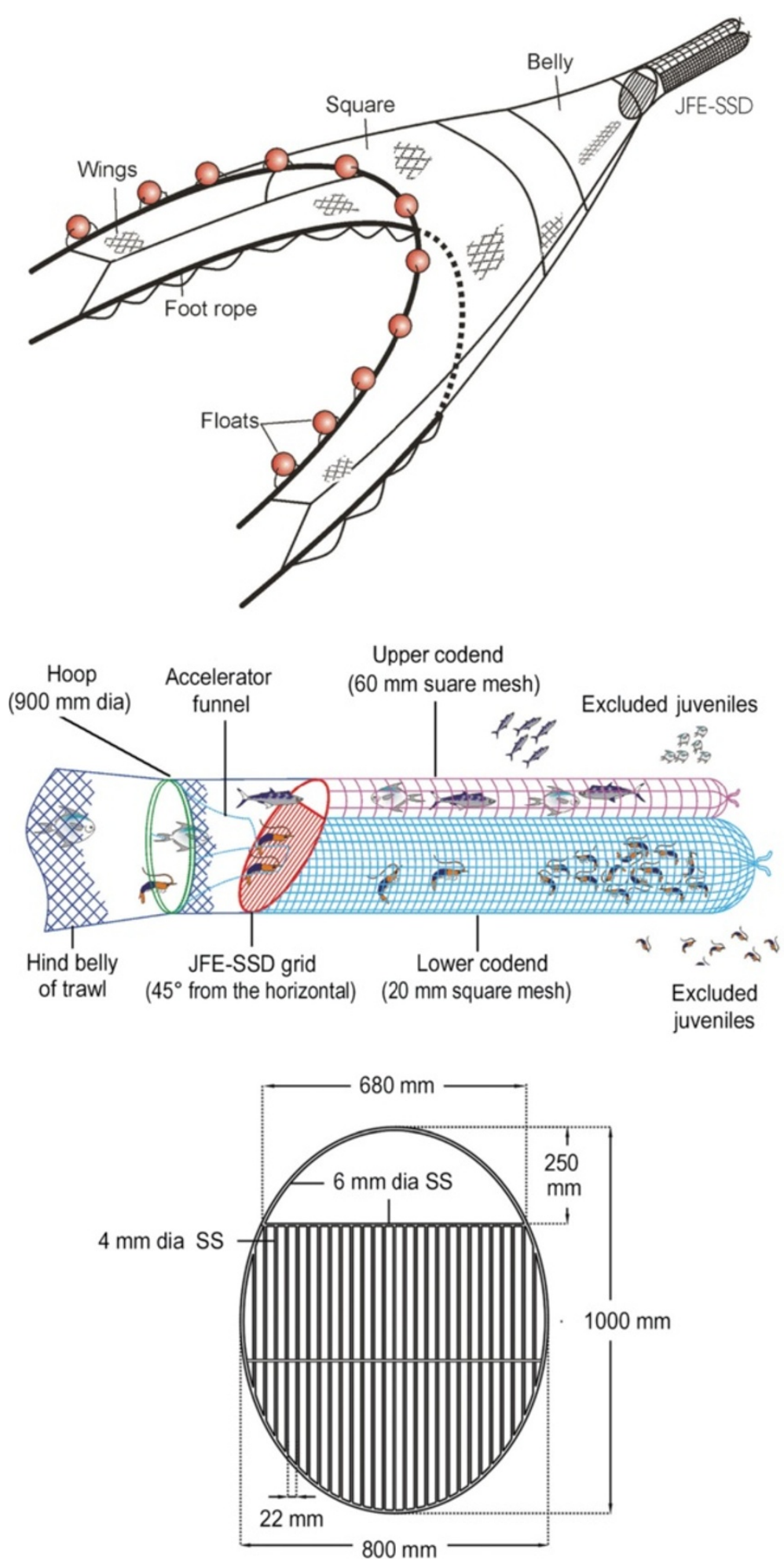

Figure 5 JFE-SSD: method of installation (top and middle) and design drawing of JFE-SSD grid (bottom).

case of Thryssa mystax, length class 101-110 mm TL showed 100\% exclusion while larger length classes (111$170 \mathrm{~mm}$ TL) showed exclusion rates of $25-68 \%$.
The estimates of mean selection length $\left(\mathrm{L}_{50}\right)$ and selection range in respect of Ambassis ambassis, Cynoglossus macrostomus, Epinephelus diacanthus, Johnius borneensis, 

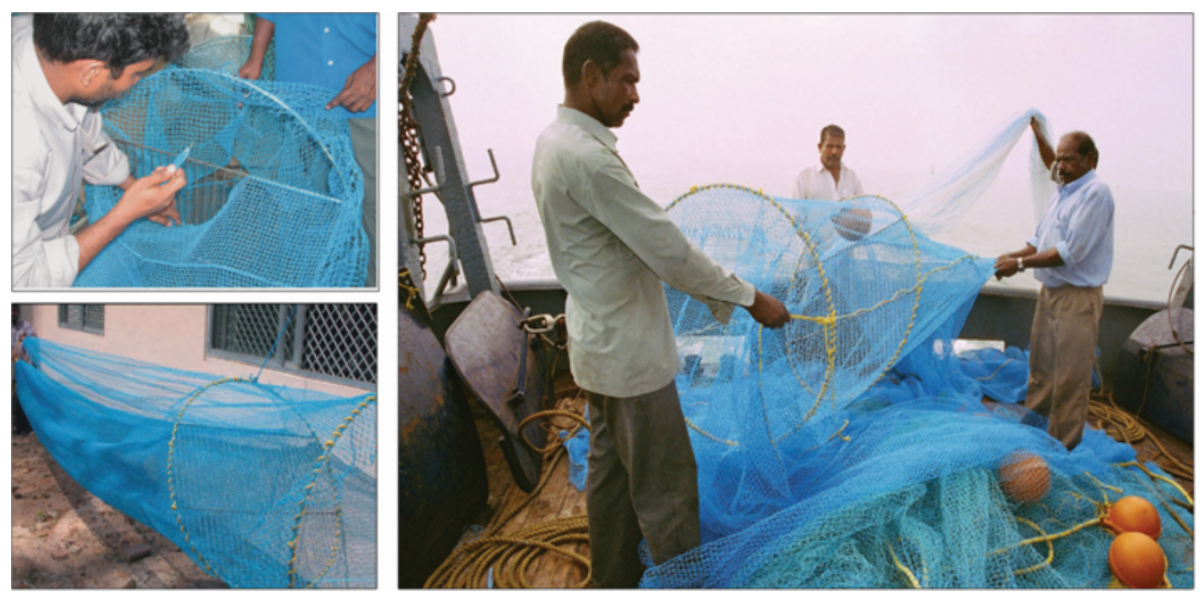

Figure 6 Views of JFE-SSD under fabrication (upper left), ready for installation (lower left) and its operation (right).

Lepturacanthus savala, Megalaspis cordyla, Sardinella albella, Sardinella longiceps, Secutor insidiator, Stolephorus waitei and Thryssa mystax were derived (Table 4). Selectivity curves and mean selection lengths indicate that JFE-SSD is able to provide escape opportunities to juveniles and sub-adults. $\mathrm{L}_{50}$ values higher than length at first maturity $\left(\mathrm{L}_{\mathrm{m}}\right)$ values (Modayil and Jayaprakash 2003; Froese and Pauly 2011) indicate better exclusion opportunities for immature fishes below $\mathrm{L}_{\mathrm{m}}$. $\mathrm{L}_{50}$ values in respect of Ambassis ambassis and Thryssa mystax were higher than $\mathrm{L}_{\mathrm{m}}$ values reported. Length based analysis of catches shows that while considerable quantities of juveniles were excluded through upper codend, sizeable amount of fishes of smaller length groups were retained in lower codend. The escapement from upper codend was $2.40 \pm 0.44$ and $0.06 \pm 0.02 \mathrm{~kg} \mathrm{~h}^{-1}$ respectively for fishes and shrimps. Considering the $\mathrm{L}_{50}$ values for the species studied, we conclude from the results that there has been considerable exclusion of juveniles from upper codend.

We have observed that a standard commercial trawl, used in the small-scale mechanized sector, can be fitted with JFE-SSD, by replacing conventional codend, in about half an hour, in field conditions. Clogging of the grid bar interspaces due to plastic refuse or decaying vegetation when they are prevalent in the fishing grounds has been observed to influence the efficiency of sorting and target catch retention, as they tend to block the interspaces of grid bars (unpublished observations).

Results indicate that JFE-SSD has excellent juvenile bycatch reduction and pre-sorting capabilities. During JFE-SSD operations off southwest coast of India, we have observed a reduction in bycatch by $29 \%$ with shrimp loss of less than $3 \%$. The device has shown potential to reduce the bycatch of juveniles of finfishes, shrimps, crabs and cephalopods and small sized fishes of low commercial
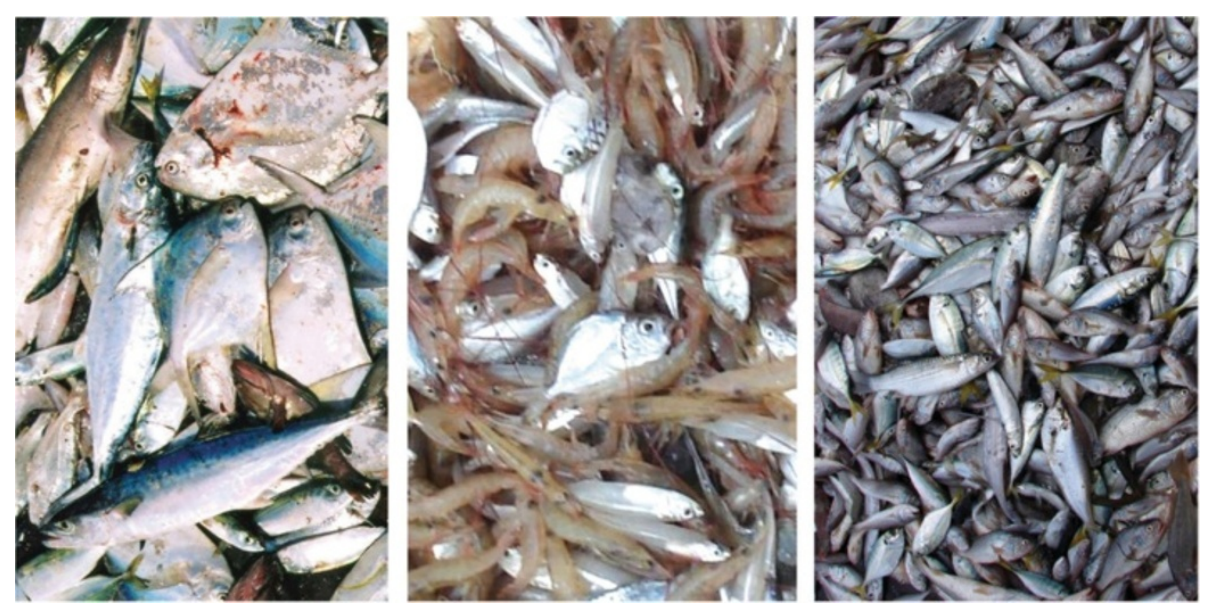

Figure 7 Views of catch from JFE-SSD operations: upper codend (left), lower codend (middle) and excluded catch (right). 


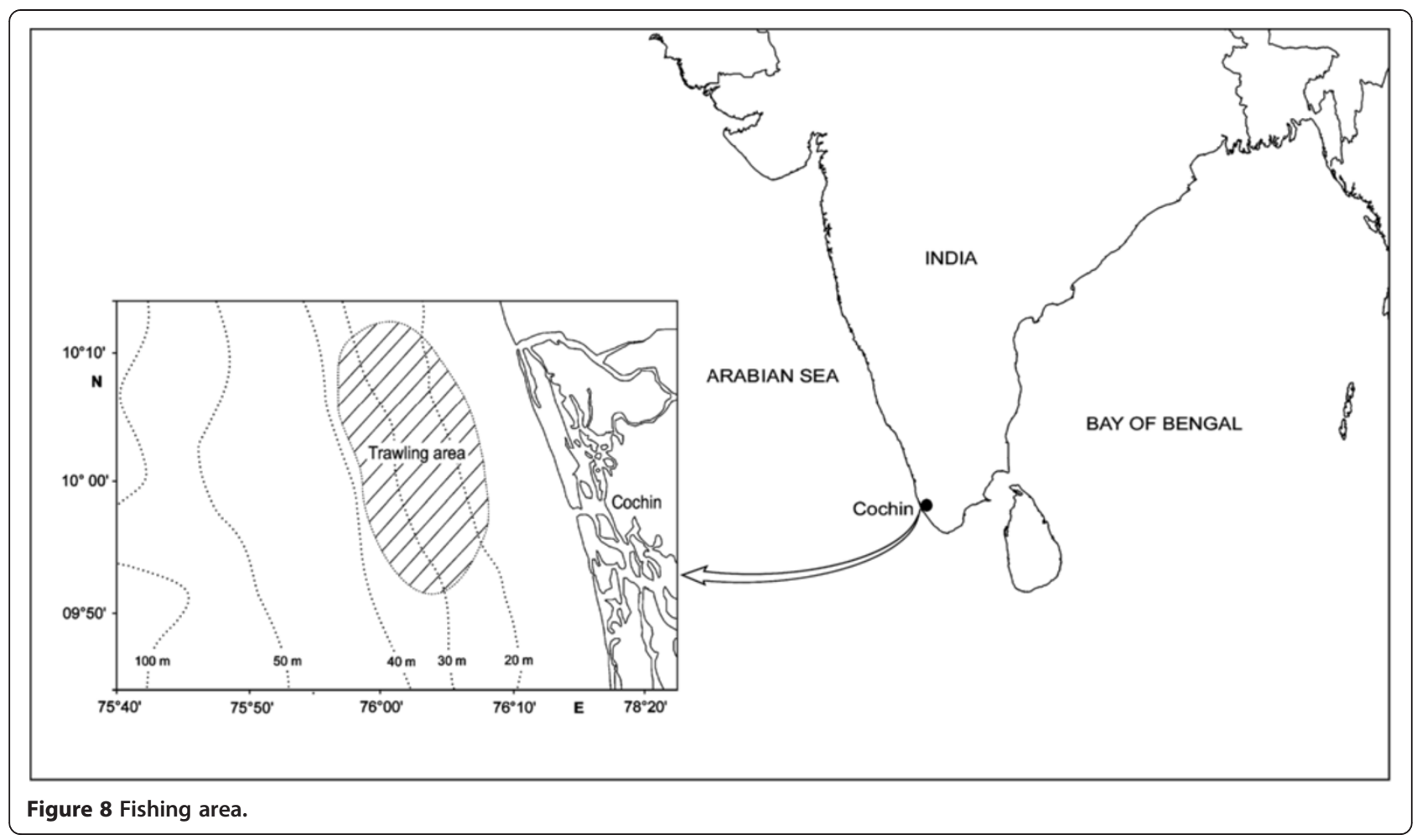

value, which will support sustainability of the resources and protection of biodiversity. The fishermen will be able to retain large fishes, which may enhance the overall revenue realized from trawling operations. Quality of the shrimps is expected to be better due to minimization of physical pressure caused by accumulation of larger fishes, which is known to take place in conventional codends. The in situ sorting effect was very pronounced in the shrimp species and about $97 \%$ of the shrimp catch was retained in lower codend. The in situ sorting effect and separation of shrimps from finfishes and cephalopods may help to reduce the sorting time and increase useful fishing time of the trawler fishermen and thus enhance the profitability of fishing operations. Increase in towing time can be expected due to slow filling of codend as a result of reduction of non target fishes and juveniles. Fuel saving also can be expected due to drag reduction caused by the escapement of non-target species, from codend.

We have successfully demonstrated installation and operation JFE-SSD to trawler fishermen at fishing villages in Ratnagiri (Maharashtra, India), during 12-14 April 2008, under a collaborative initiative on conservation of trawl caught resources and reduction on the negative impact of trawling on juveniles, of Central Institute of Fisheries Technology (Cochin), College of Fisheries (Ratnagiri) and Cameron International (Mumbai) (Boopendranath et al. 2008). Fishermen did not report any specific difficulties in installation and operation of the device. Enabling policy initiatives and legislation and a rights based regulated access system based on a strong inclusive participatory management seem to be necessary for facilitating large scale adoption of such devices (Boopendranath 2009).

\section{Conclusions}

The JFE-SSD can be easily installed by substituting the conventional codend in a standard shrimp trawl without any alteration in the trawl design. The device reduces bycatch of juveniles of commercially important finfishes, shrimps, crabs and small sized fishes of low commercial value, which will be beneficial for sustainability of resources. The study implies that the device has the potential advantage of retaining larger fishes of higher market value. The in situ sorting effect and separation of shrimps from other resources have the potential to reduce the sorting time and increase useful fishing time.

This is the first report of the experimental trials using the newly developed JFE-SSD and the results showed that it has the capacity to pre-sort the catch and favorable bycatch exclusion characteristics which can be beneficially used in the fishery for responsible trawling operations. Further optimization of JFE-SSD, particularly to reduce the finfish catches in lower codend, can be attempted and demonstration of the device in the commercial fishery setting in different fishing areas is required. 


\section{Methods}

Juvenile Fish Excluder cum Shrimp Sorting Device (JFESSD) replaces the conventional codend of the shrimp trawl. The device consists of an oval grid made of stainless steel rods having bar spacing of $22 \mathrm{~mm}$ kept at $45^{\circ}$ angle to the horizontal. The grid is provided with a $250 \times 680$ $\mathrm{mm}$ top opening which leads to an upper codend with large square meshes $(60 \mathrm{~mm})$. A funnel made of netting (20 mm mesh size) guides the catch components towards the lower side of the oval grid kept at $45^{\circ}$ angle to the horizontal which separates shrimp from rest of the catch. Shrimps pass through grid bar spacing and are retained in lower codend made up of $20 \mathrm{~mm}$ square mesh netting. Juvenile shrimps escape through $20 \mathrm{~mm}$ size square meshes of lower codend. The large fishes and cephalopods are deflected upwards to $250 \times 680 \mathrm{~mm}$ wide opening provided at the top of the grid and enter into upper codend with large square meshes $(60 \mathrm{~mm})$. Juveniles of finfishes and cephalopods and low value small sized finfishes, which have entered upper codend escape through large square meshes (Figure 5).

Views of JFE-SSD under fabrication, a finished JFE-SSD ready for installation and its operation are shown in Figure 6 and typical catch from upper and lower codends and excluded catch during JFE-SSD installed operations are given in Figure 7. The experimental field trials using JFE-SSD were conducted off Cochin, south-west coast of India (Figure 8), during November-December 2005 in the traditional shrimp trawling ground off Cochin. The JFESSD was fitted to a shrimp trawl of $29.6 \mathrm{~m}$ head rope rigged with $87 \mathrm{~kg} \mathrm{~V}$-form otter boards and operated from Research Vessel MFB Matsyakumari (Stern Trawler: $17.5 \mathrm{~m} \mathrm{~L} \mathrm{OA} ; 277 \mathrm{hp}$ ). Covered codend technique was used for performance evaluation with respect to exclusion from upper codend (Pope et al. 1975; Sparre and Venema 1998). A cover fabricated using $20 \mathrm{~mm}$ diamond mesh polyamide netting which was 1.5 times the length and width of upper codend (Stewart and Robertson 1985), was used for retaining the catch excluded from upper codend. No cover was provided in lower codend.

The duration of haul was fixed at 1 hour and after each haul, catches from different codends were sorted and kept separately in trays for length and weight measurements. When shrimp catches were very high, a sub-sample weighing not less than $25 \%$ of total weight was used for measurements. The length and weight of each individual was measured to the nearest millimeter and gram respectively. Catches were normalized to CPUE $\left(\mathrm{kg} \mathrm{h}^{-1}\right)$ and used for analytical comparisons. Consistency was maintained in deployment and retrieval procedures of the gear during experimental operations to minimize operational errors.

The statistical analysis were carried out using $R$ software (R Development Core Team 2011). One-way ANOVA was used for the comparisons and whenever the data did not follow the assumption of normality, the data was $\ln +1$ transformed and used for comparisons. The Anderson-Darling procedure was used to compare the length-frequency of species caught in upper and lower codends.

\section{Abbreviations \\ JFE-SSD: Juvenile fish excluder cum shrimp sorting device; TL: Total length; CPUE: Catch per unit effort.}

\section{Competing interests}

The authors declare that they have no competing interests.

\section{Authors' contributions}

MRB, PP, TRG and SS have been involved in conception and design of Juvenile Fish Excluder cum Shrimp Sorting Device; acquisition, analysis and interpretation of data and preparation of the manuscript. VRM has performed the statistical analysis and participated in interpretation of data and preparation of the manuscript. All authors read and approved the final manuscript.

\section{Acknowledgements}

This work was done under the Indian Council of Agricultural Research Ad-hoc Project entitled Bycatch Reduction Devices for Selective Shrimp Trawling (Project Code No. 0644003). The authors wish to thank the Director, Central Institute of Fisheries Technology for providing the facilities to conduct the studies. They also wish to acknowledge World Wildlife Fund (WWF), USA, for the recognition given for the design concept of JFE-SSD by way of the runner-up prize during the International Smart Gear Competition-2005.

\section{Author details}

${ }^{1}$ Central Institute of Fisheries Technology, CIFT Junction, P.O. Matsyapuri, Cochin 682 029, India. ${ }^{2}$ Marine Products Export Development Authority, MPEDA House, Panampilly Avenue, Cochin 682 036, Kerala, India. ${ }^{3}$ Central Institute of Fisheries Nautical and Engineering Training, Fine Arts Avenue, Cochin 682 016, India.

Received: 29 November 2012 Accepted: 14 June 2013 Published: 21 June 2013

\section{References}

Boopendranath MR (2009) Responsible fishing operations. In: Meenakumari B, Boopendranath MR, Pravin P, Thomas SN, Edwin L (eds) Handbook of fishing technology. Central Institute of Fisheries Technology, Cochin

Boopendranath MR (2012) Technologies for responsible fishing, Chapter 2. In: Nambudiri DD, Peter KV (eds) Advances in harvest and post-harvest technology of Fish. New India Publishing Agency, New Delhi

Boopendranath MR, Pravin P, Gibinkumar TR, Sabu S (2008) Bycatch reduction devices for selective shrimp trawling. In: Final report on ICAR Adhoc Project (Code No. 0644003). Central Institute of Fisheries Technology, Cochin

Boopendranath MR, Sabu S, Gibinkumar TR, Pravin P (2010) Soft bycatch reduction devices for bottom trawls. Fish Technol 47(2):99-110

Brewer D, Rawlinson N, Eayrs S, Burridge C (1998) An assessment of Bycatch Reduction Devices in a tropical Australian prawn trawl fishery. Fish Res 36:195-215

Broadhurst MK (2000) Modifications to reduce bycatch in prawn trawls: a review and framework for development. Rev Fish Biol Fish 10:27-60

Broadhurst MK, Brand CP, Kennelly SJ (2012) Evolving and devolving bycatch reduction devices in an Australian penaeid-trawl fishery. Fish Res 113:68-75

CEFAS (2003) A study on the consequences of technological innovation in the capture fishing industry and the likely effects upon environmental impacts, The Centre for Environment, Fisheries and Aquatic Science (CEFAS). Final Report submitted to Royal Commission on Environmental Pollution. Westminster, London

CMFRI (2013) Estimated marine fish landings in India. Central Marine Fisheries Research Institute, Cochin, http://www.cmfri.org.in/annual-data.html. Accessed 1 June 2013

Courtney AJ, Tonks ML, Campbell MJ, Roy DP, Gaddes SW, Kyne PM, O'Neill MF (2006) Quantifying the effects of bycatch reduction devices in Queensland's 
(Australia) shallow water eastern king prawn (Penaeus plebejus) trawl fishery. Fish Res 80:136-147

Criales-Hernandez MI, Duarte LO, García CB, Manjarrés L (2006) Ecosystem impacts of the introduction of bycatch reduction devices in a tropical shrimp trawl fishery: Insights through simulation. Fish Res 77:333-342

Eayrs S (2007) A guide to bycatch reduction in tropical shrimp-trawl fisheries. Revised edn. FAO, Rome

Eayrs S, Hai NP, Ley J (2007) Assessment of a juvenile and trash excluder device in a Vietnamese shrimp trawl fishery. ICES J Mar Sci 64:1598-1602

Froese R, Pauly D (eds) (2011) FishBase. World Wide Web electronic publication, www.fishbase.org/, version (08/2011)

Hannah RW, Jones SA (2007) Effectiveness of bycatch reduction devices (BRDs) in the ocean shrimp (Pandalus jordani) trawl fishery. Fish Res 85:217-225

Heales DS, Gregor R, Wakeford J, Wang YG, Yarrow J, Milton DA (2008) Tropical prawn trawl bycatch of fish and seasnakes reduced by Yarrow Fisheye Bycatch Reduction Device. Fish Res 89:76-83

Isaksen B, Valdemarsen JW, Larsen RB, Karlsen L (1992) Reduction of fish by-catch in shrimp trawl using a rigid separator grid in the aft belly. Fish Res 13:335-352

Kelleher K (2005) Discards in the world's marine fisheries - an update. FAO Fisheries Technical Paper 470, Rome

Kendall D (1990) Shrimp retention characteristics of the Morrison soft TED: a selective webbing exclusion panel inserted in a shrimp trawl net. Fish Res 9:13-21

Kennelly SJ, Broadhurst MK (2002) By-catch begone: changes in the philosophy of fishing technology. Fish Fish 3:340-355

Kennelly SJ (ed) (2007) Bycatch Reduction in the World's Fisheries, Reviews: Methods and Technologies in Fish Biology and Fisheries Vol. 7. Springer, The Netherlands, p 288

Modayil MJ, Jayaprakash AA (2003) Status of exploited marine fishery resources of India. Central Marine Fisheries Research Institute. Kochi, India

Pope JA, Margetts AR, Haley JM, Akyuz EF (1975) Manual of methods of stock assessment Part 3: Selectivity of fishing gear. FAO, Rome, FAO Fish. Tech. Rep. No. 41, rev 1

Pramod G (2010) Illegal, unreported and unregulated marine fish catches in the Indian Exclusive Economic Zone. In: Pitcher TJ (ed) Policy and ecosystem restoration in fisheries, Field report. Fisheries Centre, University of British Columbia, BC, Vancouver, Canada

Pravin P, Sabu S, Gibinkumar TR, Boopendranath MR (2011) Hard bycatch reduction devices for bottom trawls - a review. Fish Technol 47(2):107-118

R Development Core Team (2011) R: A language and environment for statistical computing. R Foundation for Statistical Computing, Vienna, Austria, http://www.R-project.org/. ISBN 3-900051-07-0

Robins JB, McGilvray JG (1999) The AusTED II, an improved trawl efficiency device 2. Commercial performance. Fish Res 40:29-41

Rogers DR, Rogers BD, de Silva JA, Wright VL, Watson JW (1997) Evaluation of shrimp trawls equipped with bycatch reduction devices in inshore waters of Louisiana. Fish Res 33:55-72

Salini J, Brewer D, Farmer M, Rawlinson N (2000) Assessment and benefits of damage reduction in prawns due to use of different bycatch reduction devices in the Gulf of Carpentaria, Australia. Fish Res 45:1-8

Sparre P, Venema SC (1998) Introduction to tropical fish stock assessment. Part 1: Manual. FAO Fish. Tech. Pap. 306/1 Rev. 2. FAO, Rome, http://www. fao.org/docrep/W5449E/w5449e01.htm

Stewart PAM, Robertson JHB (1985) Small mesh codend covers. Scott Fish Res Rep 32:1-11

Suuronen P, Chopin F, Glass C, Lokkeborg S, Matsushita Y, Queirolo D, Rihan D (2012) Low impact and fuel efficient fishing - looking beyond the horizon Fish Res 119-120:135-146

WWF (2005) Modifying Shrimp Trawls to Prevent Bycatch of Non-target Species in the Indian Ocean. World Wildlife Fund (WWF), Palo Alto, California, US, http://www.smartgear.org/smartgear_winners/smartgear_winner_2005. Accessed 7 July 2012

doi:10.1186/2193-1801-2-271

Cite this article as: Boopendranath et al:: Investigations on juvenile fish excluder cum shrimp sorting device (JFE-SSD). SpringerPlus 2013 2:271.

\section{Submit your manuscript to a SpringerOpen ${ }^{\odot}$ journal and benefit from:}

- Convenient online submission

- Rigorous peer review

- Immediate publication on acceptance

- Open access: articles freely available online

- High visibility within the field

- Retaining the copyright to your article

Submit your next manuscript at $\gg$ springeropen.com 